\title{
Before Macroeconomics: Pareto and the dynamics of the economic aggregate
}

\section{Mauro Boianovsky}

\section{(2) OpenEdition \\ 1 Journals}

\section{Electronic version}

URL: http://journals.openedition.org/ress/2544

DOI: $10.4000 /$ ress.2544

ISSN: 1663-4446

\section{Publisher}

Librairie Droz

\section{Printed version}

Date of publication: 15 December 2013

Number of pages: 103-131

ISBN: 978-2-600-01805-0

ISSN: 0048-8046

\section{Electronic reference}

Mauro Boianovsky, "Before Macroeconomics: Pareto and the dynamics of the economic aggregate ", Revue européenne des sciences sociales [Online], 51-2 | 2013, Online since 01 January 2017, connection on 20 March 2020. URL : http://journals.openedition.org/ress/2544 ; DOI : https://doi.org/10.4000/ ress. 2544

\section{(C) Librairie Droz}




\title{
BEFORE MACROECONOMICS: PARETO AND THE DYNAMICS OF THE ECONOMIC AGGREGATE
}

\author{
MAURO BOIANOVSKY \\ University of Brasilia \\ mboianovsky@gmail.com
}

\begin{abstract}
Pareto based his interpretation of business cycles on a disaggregated general equilibrium system with dynamics determined by frictions (or "inertia"). The present article investigates his interpretation of the motion of the economic aggregate, in the sense of the set of individual consumers and producers forming the economic system in general equilibrium. Did Pareto develop a representative agent model avant la lettre? This is discussed from the double perspective of Pareto's interpretation of the synchronism of economic "vibrations" and his rejection of the analytical relevance of the "Robinson Crusoe" economy. He was aware that the general equilibrium system could not provide a practical method of solving the equations for each and every individual. This has been called the "Cournot problem" in the literature, as Augustin Cournot was the first to state it. Pareto reacted to that problem by defining economics as the study of average phenomena involving large numbers in repeated markets.
\end{abstract}

Keywords: Vilfredo Pareto, macroeconomics, economic aggregate, averages, Cournot problem.

Résumé. Pareto fonde son interprétation des cycles économiques sur un système d'équilibre général caractérisé par des dynamiques de friction (ou d'inertie). Le présent article examine la manière dont il interprète les grands mouvements économiques à l'aune de l'ensemble des individus (consommateurs et producteurs) constituant le système économique à l'équilibre général. Pareto développe-t-il un modèle à agents représentatifs avant la lettre? Cette thèse fait l'objet d'une discussion dans la double perspective de l'interprétation par Pareto du synchronisme des «vibrations économiques» et de son rejet de la pertinence analytique du cas d'une économie à la «Robinson Crusoe». II était conscient du fait que le système de l'équilibre général ne saurait fournir de méthode pratique apte à résoudre les équations propres à chacun des individus. Cette aporie formulée une première fois par Augustin Cournot est connue en science économique sous le nom de «problème de Cournot». En réaction à ce problème, Pareto entreprend de définir la science économique comme l'étude des phénomènes moyens impliquant un grand nombre d'agents et sur des marchés répétés.

Mots-clés: Vilfredo Pareto, macroéconomie, ensemble économique, moyennes, problème de Cournot. 
INTRODUCTION

Macroeconomics established itself as a separate field in the i930s, when the general interdependence between agents in the economy as a whole started to be modelled at an aggregate level with a small number of markets (consumption and capital goods, money, bonds and labour). This is well illustrated by John Hicks's (1937) IS-LM model and by part IV of his Value and Capital (see e.g. De Vroey, 2004). Hicks's approach to macroeconomics combined different strands in economic theory: Léon Walras and Vilfredo Pareto's general equilibrium analysis, Knut Wicksell's saving-investment framework, Irving Fisher and Alfred Marshall's quantity theory of money tradition, and Keynes's theory of the determination of aggregate output and employment. Hicks ([1939] 1946) referred extensively to Pareto's theory of consumer behaviour and general economic equilibrium in other parts of his book, but, like most macroeconomists at the time, he did not take notice of Pareto's attempted treatment of the "dynamics of the economic aggregate" in chapter IV of the second volume of the Cours d'Économie politique (I964 [1896-I897]; translated as "Economic Crises", 2005 [1896-1897]).

In contrast with prevailing Wicksellian and Fisherian aggregative approaches to fluctuations in nominal and real variables, Pareto based his interpretation of business cycles on a disaggregated general equilibrium system with dynamics determined by frictions (or "inertia”). Except for a few Italian economists, Pareto's approach had no impact on business cycle theory in the interwar period. This reflects the fact that Italian economic culture found it difficult to accept the shift to aggregative macroeconomic models that came to dominate economic dynamics at the time (Pomini and Tusset, 2009). Indeed, Giovanni Demaria (1952 [1949]), long-time editor of the Giornale degli economisti, claimed that Pareto's main contribution to economics was to frame equilibrium as a complex relation between individuals instead of "ephemeral" aggregates. The present article investigates Pareto's interpretation of the motion of the economic aggregate, in the sense of the set of individual consumers and producers forming the economic system. This is distinct from the usual notion of economic aggregates as measured by adding up the algebraic sum of 
the individual supply and demand functions over the whole economy. Pareto's general "conception of economic aggregate finds an analogy in the conception which an astronomer has of the solar system when he has apprehended the general equations of mechanics" (I897, p.493).

From Pareto's general equilibrium perspective, economic activity is geared to the satisfaction of consumers' wants. The microeconomic theory of consumer behaviour provides the foundation of the modelling of the economic system, which is seen as a circular flow between individuals and firms in the markets for goods and factor services, as illustrated by figure 40 of his Manuel d'Économie politique (translated as Manual of Political Economy, I97 I [1909]; see also Weintraub, 1979, chapter I). Pareto regarded the "individual economy" -in the sense of the pure-exchange competitive equilibrium model, where prices are taken as given by individual traders - as the benchmark for economic theory as a whole. In paragraph 928 of his Cours (op.cit.), he put forward a model of cyclical oscillation in individual consumption, and claimed that it established the ability of pure economics to explain the movements of the economic aggregate. It was the first attempt (even if not entirely successful) in the literature to infer the business cycle from optimal economic behaviour (Boianovsky and Tarascio, 1998; Bridel, 20I2). Did Pareto develop a representative agent model avant la lettre? This is discussed below, from the double perspective of Pareto's interpretation of the synchronism of economic "vibrations" and his rejection of the analytical relevance of the Robinson Crusoe economy.

Pareto imported from physics not just the mechanical metaphor but also the experimental method as the only scientific procedure. Differently from Walras, he regarded general equilibrium as an instrument to understand economic facts through successive approximations, not as a normative ideal (Ingrao and Israel, 1990, chapter 5; Marchionatti and Gambino, 1997). Although aggregate variables were not part of his pure economics equations, they were important in testing demand and other economic functions on aggregate data through statistics. Pareto's empirical discussion of the business cycle was based on changes in aggregate consumption and savings as indicated by data on the velocity of circulation of bank deposits. He was aware that the general equi- 
librium system, for informational and algebraic reasons, could not provide a practical method of solving the equations for each and every individual. This has been called the "Cournot problem" in the literature, as Augustin Cournot was the first to state it. As documented below, Pareto reacted to that problem by defining economics as the study of average phenomena involving large numbers in repeated markets. Whereas Pareto's economics was based on the assumption of essential similarities between economic agents, in his sociology Pareto ([1916] 1935) stressed instead social heterogeneity among individuals and their division into aggregate socio-economic classes.

\section{GENERAL EQUILIBRIUM AND AVERAGES}

In chapter II of his Recherches, titled "Of the Social Income", Cournot (I897 [1838]) called attention to some analytical hurdles entailed by interdependence in the economic system. According to Cournot, a "complete and rigorous" solution of the problems relative to any of the parts of the economy makes it necessary "to take the entire system into consideration". However, "this would surpass the powers of mathematical analysis and of our practical methods of calculation, even if the values of all constants could be assigned to them numerically" (ibid., p.r27-28). This pointed to the general equilibrium approach later introduced by Walras and further developed by Pareto (Schumpeter, 1954, p.960; Solow, 2007, p.107). Pareto claimed the theoretical relevance of general equilibrium analysis as "the only means as yet known" for understanding the determination of the value of economic variables. But at the same time he acknowledged that general equilibrium equations "cannot be of practical use to us for numerical calculations of quantity and price", which was precisely the problem Cournot pointed out. Even assuming that "we have overcome all the difficulties in the way of acquiring knowledge of the data of the problem", which is "already an absurd hypothesis", there remains the "practical matter that is beyond the power of algebraic analysis" to solve the "fabulous number of equations which a population of forty million individuals and several thousand goods would entail” (Pareto, I97 I [1909], p.i7I). 
Hayek (1942, p.29I) quoted Pareto's remarks and noted its connection with the passage from Cournot. As observed by Hayek, Pareto clearly saw the distinction between the ability of the system of equations to provide a comprehensive picture of the mutual interdependence of market phenomena and its inability to predict the precise effects of any particular change (see also Hayek's 1975 Nobel lecture, p.437). After Hayek, Friedman argued that Walras's general equilibrium emptied "Cournot's problem" (1955, p.904) - as Friedman called it for the first time-of its practical content by producing an idealized picture of the economic system with no application to concrete issues. The difficulties posed by the Cournot problem have been part of economic theory (especially macroeconomics) ever since (Hoover, 1988, chapter 9.2). Cournot's own attempted suggestion was to introduce aggregate concepts such as "social income" and by that reduce the number of variables (I897 [1838], chapters II and I2). He did not get very far in anticipating the macroeconomic approach, though (Schumpeter, 1954, p.960; Solow, 2007).

The Cournot problem is even more acute in Pareto's than in Walras's version of the general equilibrium system. This is because, differently from Walras's complex procedure, the Italian economist did not aggregate individual supply and demand equations to obtain market supply and demand functions (Demaria, 1952 [1949]; van Daal and Walker, 1990). According to Demaria, Pareto, by insisting on the subjective character of economic interdependence and interpreting the system of equations as "a complex of necessarily individual relations" (ibid., p.633), went farther than Walras. Interdependence is a subjective datum in Paretian economics, in the sense that the economic problem consists of the choices of individuals, "not of the mass", as put by Demaria. In particular, "all relations which appear as aggregate-and which lead to the so-called macroeconomics-are considered as accidental, ephemeral, and impermanent, only approximately universal or not universal at all” (ibid.). A seen by Demaria (ibid., p.637), Pareto's discussion of general equilibrium as exclusively a system of relations among individuals was his major contribution to economics. Demaria acknowledged that the temptation to using "mass categories" comes from the attempt to overcome an "infinitely complex reality", 
but claimed that aggregative or "synthetic" reasoning did not add new insights to the pure universal hypotheses of disaggregative microeconomic general equilibrium (ibid., p.636-637; see Weintraub, 1979, p.7). Pareto (1964 [1896I897], §I00) showed that it is not necessary to aggregate over individuals in order to establish that all markets can clear. This approach may entail the disappearance of markets from view and render the Cournot problem more difficult to tackle, which might explain Walras's cold reception of Pareto's version of general equilibrium (van Daal and Walker, 1990, p.499-500).

W.S. Jevons's (1965 [1871]) notion of "trading bodies" provided yet another way to deal with the difficulties posed by the large amount and variety of individuals in the economy. This is related to, but not quite the same as, the Cournot problem. Although economic theory investigates the "conditions of a mind", practically it focuses on an "aggregate of individuals". This is so because the operation of general economic laws does not apply to the vagaries of individual behaviour, whose actions are "beyond the analytic power of science". Such laws can only be detected in average or aggregate behaviour, on the assumption of a "high probability that accidental and disturbing causes will operate in the long run [...] so as to neutralise each other". Therefore, claimed Jevons, "questions which appear, and perhaps are, quite indeterminate as regards individuals, may be capable of exact investigation and solution to great masses and wide averages" (ibid., p.15-16). The behaviour of the aggregate or average agent is more stable and continuous than that of an individual agent, which means that differential calculus can only be used in the first case. Jevons's concept of the "trading body" as representing any trader (whether an individual or a group of individuals) in a market aimed at minimising the problem of commodity indivisibility and discontinuities in exchange theory (White, 200I). He defined a trading body as "any body either of buyers or sellers. The trading body may be a single individual in one case; it may be the whole inhabitants of a continent in another; it may be the individuals of a trade diffused through a country in another" (Jevons, I965 [I87I], p.88). 
Aspects of Jevons's argument-that aggregate demand functions in every market are continuous because of the operation of the law of large numbers - could be also found in Cournot (I897 [1838], p.49-50), Walras (1954 [1874], p.95) and Marshall (1990 [1890], p.83). However, the same was not true of Jevons's concept of "trading body", with its not fully developed notion of collective marginal utility. Walras (ibid., p.206) and Marshall (ibid., p.674) rejected the concept for its reference to a world of "fictitious mean" (Jevons, op.cit., p.9o) and for ignoring differences of marginal utility of money among its members, respectively. There are no records of Pareto's reactions to Jevons's trading body. He would not reject it on the same grounds as Walras, as the notion of average phenomena played an important role in Pareto's economic framework (Baranzini and Bridel, 2005). In one of his first articles, Pareto stated "Political Economy cannot but be a science of averages, and it cannot aspire at predicting and explaining merely acts of single individuals" (2007 [1892-1893], p.65). In the same vein, Pareto pointed out that economic theory is only able to predict general market demand, not singular demand by a given individual (1964 [1896-1897], §37). Economics would reach "absurd results" if it studied "individual and singular" phenomena instead of "general and average” ones (ibid., §645). As part of Pareto’s positivist methodology, the explanation of individual choices should be kept separated from psychology and the quest for internal unobservable factors. Accordingly, economics should aim at the logic of observable repeated market behaviour (see also Teira, 2006). Economic propositions in general (and demand theory in particular) must be tested on aggregate statistical data.

In political economy [...] we consider only average phenomena and those involving large numbers. We speak of individuals, not in order actually to investigate what one individual consumes or produces, but only to consider one of the elements of a collectivety and then add up the consumption and the production of a large number of individuals (Pareto, I97 I [1909], p.123).

The premise that economics studies only "average and frequently repeated phenomena" implied that quantities in the equations should be expressed as flows per unit of time (Pareto, I955 [19II], p.69). Pareto clarified that the substitution of continuous variations for discontinuous ones could led to errors 
only if what was involved was a study of "individual psychology" instead of a "science of averages and large numbers" (2008 [1900], p.462). This was explained in the chapter about business cycles, where he pointed out that, while investigating the conditions of equilibrium,

we should eschew the consideration of isolated examples of consumption and devote our attention to daily, monthly or annual consumption. Moreover, this is the true purpose of political economy. If a mother happens to buy her son a bar of chocolate, or if a worker, perspiring from his labours, drinks a glass of bear, these are psychological facts. Political economy must confine itself to considering the annual consumption of chocolate or beer. We must consider averages and equalise, by means of compensation, the differences between the social facts we have isolated (Pareto, 1964 [1896-1897], §928; 2005 [1896-1897], p.8).

Economics does not take into account details of different choices of each individual, just like "the geographer describes the earth without counting the grains of sand" (ibid).

Pareto's concept of equilibrium as an "average state" indicates that he understood it as a "statistical equilibrium" with variations compensating one another. This is illustrated in the Cours (ibid., §7I8, §925) by the notion that in a given industry in equilibrium some firms make losses and others make profits, although in the aggregate they break even. It was only later that Pareto made explicit that, in both economics and sociology, equilibrium is "analogous to the state of statistical equilibrium in the kinetic theory of gases” (1935 [1916], §2074; see also Tusset, 2013). For instance, the statement that the consumption of a commodity is constant through time does not mean that every individual consumes the same amount each year, as "such numbers vary widely". It does mean that "the variations more or less offset one another, so that the resultant is zero or, to be more exact, approximately zero", according to the "laws of probabilities". This was similar to Jevons's resort to probabilities to justify the use of average variables. The common influence behind both Jevons and Pareto was Adolphe Quetelet's (I99I [1835])

I On Pareto's project to separate economics from psychology and study the "facts" of choice instead of their "essence", see Bruni, 2009. 
seminal concept of l'homme moyen based on the view that human behaviour is normally distributed according to the law of large numbers.

Quetelet's influence on Jevons has been well documented in the literature (Mosselmans, 2005), but the role of the "average man" in Pareto's framework has been usually overlooked. Pareto referred to Quetelet's (op.cit.) demographic studies in his chapter on population ${ }^{2}$ and observed that

The works of Quetelet are still a model of method to be deployed in social sciences. The jokes some scientists make about Quetelet's average man only prove that one may be an expert in a particular science and yet know absolutely nothing about social sciences (Pareto, 1964 [1896-1897], §178).

Quetelet's project of "social physics" - in the sense of reducing the methodology of social sciences to that of physical sciences by means of statistics -was dear to Pareto. This clearly shows in the detailed discussion of index numbers of purchasing power of money and real income in paragraphs 383-400 and 643-652 of his Cours, a topic that also attracted Jevons's attention. From Pareto's perspective, the main issue was the impossibility to rigorously compare the ophelimity (utility) of two different men or of the same man in two distinct moments. The way to lift the difficulty was to suppose men-that "may represent the averages of certain classes"-always identical to themselves while economic conditions change. Such "hypothetical man" is an "average man" that differs from the "real man", but this is true of all sciences dealing with "human sensations" (ibid., §384). There is no contradiction between the proposition that the ophelimities of different individuals cannot be compared and the daily comparisons of welfare of certain individuals with the welfare of others. While the first one deals with two determinate individuals, the second refers to certain "average types" that share a "certain background of qualities common to the compared men", even if differences are taken into account in the next stage. This explains why the welfare of an Englishman can be compared to the welfare of a Frenchman, or why one can decide whether medieval man was more or less happy than modern man (ibid., §645-649). 
Apart from a brief cryptic remark that Pareto "considers dynamic abstractions as a mere problem of averages” (1952 [1949], p.647), Demaria did not dwell on Pareto's treatment of averages or the matter of their compatibility with general equilibrium analysis and focus on individual behaviour. This leads to the notion of the representative agent, discussed next.

\section{ROBINSON CRUSOE AND THE REPRESENTATIVE AGENT}

General equilibrium analysis was an attempt do deal with the difficulty derived from "the large number of individuals who $[. .$.$] in proceeding to make choices, clash,$ back each other and struggle with one another" (Pareto, 2008 [1900], p.459). Differently from some neoclassical economists in the late $19^{\text {th }}$ century (see White, 1987), Pareto rejected the use of Daniel Defoe's Robinson Crusoe as a metaphor to study decisions by maximizing economic agents. He acknowledged in the Cours (op.cit., t.II, p.399) that the metaphor of an isolated individual could illustrate some aspects of the allocation process - such as the distribution of labour effort between consumption and investment (as done by Böhm-Bawerk, I89I [1889], book I, chapter IV)-but criticized the relevance of the Crusoe economy as a representation of supply and demand theory and as a way out of the difficulty posed by the interaction between economic agents.

If we were to formulate a theory for Robinson Crusoe without his man Friday, our task would not be too difficult; but we have to elaborate a theory for a man living in society and we must concern ourselves with the many kinds of actions and reactions which are met in that case [...] We shall see that pure economics will use the same procedures as rational mechanics and has several points of contact with that science (Pareto, 2008 [1900], p.459; see also Pareto, 1963 [1898], p.125 for a similar passage).

Pareto's attitude toward the Crusoe economy was similar to Böhm-Bawerk's (I89I, p.379-38I). The Crusoe economy could illuminate the relation of men to external goods (e.g. individual demand functions for goods), but not the relation between men in the market, called "microcosm" and "macrocosm" respectively by the Austrian economist (see also Böhm-Bawerk, ı89i [I889], p.I05). Böhm-Bawerk's meaning of "macrocosm” was close to Pareto's "economic 
aggregate", in the sense of the set of relations formed by the market economic system as a whole. The term "macrocosm" was not used to denote aggregate economic variables as in "macroeconomics", although Böhm-Bawerk did contribute to what Schumpeter (1954, p.997-998) called the Quesnay-RicardoBöhm-Bawerk-Wicksell tradition of "macroanalysis" of the distribution of aggregate output. Böhm-Bawerk pointed out that the study of the "microcosm" was a necessary step for a proper understanding of the working of the "macrocosm".

Pareto's criticism of the Crusoe metaphor did not mean that he rejected individual behaviour as the foundation of general equilibrium equations. Whereas the Crusoe economy "after all, moved [economics] away considerably from reality",

on the contrary, it is useful to consider in isolation a trader who is in a market where prices are supposed to be given. There is thus a study of the individual economy, similar to the study of the movement of a material point made by dynamics. One gets closer to reality by considering two traders and, eventually, any number of them (Pareto, 1964 [1896-1897], t.II, p.399).

Pareto devised the term "individual economy" (économie individuelle) to express the choice problem of the maximizing individual consumer (2007 [I892-1893] p.19; 1964 [1896-I897], §56; 197I [1909], p.407). He often stressed the analytical identity between the equation describing the equilibrium of the consumer in pure economics and the equation of virtual movement of the equilibrium of a material point in mechanics (1964 [1896ı897], §586; 1963 [1898], p.I27; see also Donzelli, I997, section ı; Boianovsky and Tarascio, 1998, p.6). In the same vein, the "economic aggregate" corresponded to a "mechanical system" formed by a number of material points (Pareto, 1964 [1896-1897], §592; I897, p.493). The pure-exchange model of the "individual economy" provided the theoretical foundation on which general equilibrium analysis was built: the "equations given for economic equilibrium are the individual equations” (Pareto, I964 [1896-I897], §973). Surely, this did not mean that the economist knew the parameters of each equation. As explained by Pareto in the final chapter ("Résumé Général”) of his Cours, “in 
pure theory we posed equations for each individual in the aggregate, by leaving indeterminate the constants that characterize each individual" (ibid., t.II, p.408).

From both theoretical and empirical perspectives, what matters is the average outcome of the social interaction displayed by the general equilibrium system, not the solutions to each individual equation, which remain unknown. The issue is related to Jevons's notion of "trading bodies" discussed above. As suggested by Negishi (1989, p.326-327) and White (1994, p.434), the trading body concept may be interpreted as the first use of the representative individual device in economics. ${ }^{3}$ However, differently from modern usage (see e.g. Sargent, 1979, p.37I), Jevons pointed out the heterogeneity of households instead of their homogeneity-indeed, that is what was behind his notion of "average" in the first place. The average laws applying to persons in a community "will come under what I have elsewhere called the "Fictitious Mean', that is to say, they are numerical results which do not pretend to represent the character of any existing thing". This did not render the concept useless, "for the movements of trade and industry depend upon averages and aggregates, not upon the whims of individuals" (Jevons, I965 [I87I], p.90). This remark indicates that methodological individualism did not play the same role in Jevons's economics as in the modern search for the "microfoundations" of macroeconomics (see also Backhouse and Boianovsky, 20I3).

Like Jevons, Pareto pointed out the relevance of averages, but did not deploy the "trading bodies" device to represent them (except for a partial exception discussed below). According to Jevons, economic laws are not the same in the case of aggregates and individuals, "unless all those individuals were of the same character and position as regards wealth and habits" (1965 [I87I], p.I5). Differences in the "character" of particular groups (as displayed in class and race behaviour) played an important role when it came to practical applications and verification of the theory (White, 1994). Pareto brought in such differences of character and social heterogeneity at a later stage in his analysis only, when he 
established what has become known as the statistical "Pareto law" governing the functional form for income distribution among individuals (1964 [1896-I897], book III, chapter I; I97I [1909], chapter 7; see Kirman, 1998, p.28-32). The regular pattern of inequality of income distribution reflected, according to Pareto, the fact that society is hierarchically defined on the basis of physical, moral and intellectual differences among individuals (197I [1909], p.28I). This eventually led to Pareto's (1935 [1916]) sociological theory of the "circulation of elites". The individual equations used in the elaboration of the general equilibrium system are not valid anymore when social heterogeneity is taken into account:

In the Introduction we had to begin with a study of the individual economy. The laws of supply and demand that were obtained in that case are not at all those that we have when we consider a whole society, where there is a given distribution of income (Pareto, 1964 [1896-1897], §973). ${ }^{4}$

The theory of distribution leads us to gather in groups those different individuals and their corresponding equations. The laws of supply and demand then appear under a different aspect than the one they had when isolated individuals were considered (ibid., t.II, p.408-409).

Pareto, however, did not develop the equations of general economic equilibrium for different classes or groups of society. Instead, as Tarascio (1969, p.I02) has pointed out, he would approach the issue from a sociological perspective (Pareto, [1916] 1935), where the economic process would no longer be moulded in the framework of the behaviour of individual elements, but in terms of the behaviour of social aggregates and their interdependence (see also Tusset, 20I3). According to Tarascio, one should look at Pareto's sociology in order to find his macroeconomics, especially in the form of cyclical aggregate oscillations caused by the non-logical actions of "rentiers" and "speculators" groups (see also Boianovsky and Tarascio, 1998, section 4). The present discussion is restricted to Pareto's treatment of the dynamics of the economic aggregate within the limits of his pure economics, where social heterogeneity is not conspicuous. Indeed, in a letter to Vladimiro Furlan of i I October 1907 (reproduced

4 By "introduction" Pareto meant paragraphs I-I54 of the Cours, titled "Principes d'économie politique pure". 
in Pareto, 1975, p.608-609; see also Mornati, 2008, p.I8I-I82), Pareto stated that pure economics dealt with two kinds of problems: (i) "how an individual or a class of individuals entirely similar decide their choices" and (ii) "how economic goods are distributed in a society formed by such individuals or classes". The latter is the problem of "economic equilibrium" properly. Pareto added:

When we discuss a class of persons entirely similar, we mean not just physiologically similar, but also similar in the circumstances in which they find themselves, in what they own and earn, etc.; where in reality it would be better always to discuss one single individual; at least while we want to elaborate a general theory; and then, in the applications, we may try to have classes (ibid).

Pareto's claim that economic theory should deal with just one single individual may look surprising, but there is some textual evidence to support that statement. For instance, in his Manuel (I97 I [1909], chapter III, §87) he argued that the quantities of goods "transformed" by different individuals in their consumption choices might be added up, so that "any number of consumers may be replaced by a single fictitious consumer who represents them all taken together". The argument was developed diagrammatically only, not in mathematical form. In the same vein, he maintained that the indifference curves for the "collectivity [...] will follow from the indifference curves of the individuals" (ibid, §99). It is only implicit that the effects of changing income distribution (for a given aggregate income) on demand are disregarded or assumed away. This was different from the aggregation of heterogeneous utilities. In fact, in the first extension of the general equilibrium model to international trade (see Maneschi, I993), Pareto criticized J.E. Cairnes's international trade theory for assuming that there is a “certain person named 'society' and that it is the sacrifices made by that person that one considers" (I964 [I896-I897], \$859). However, "society is composed of different people, and the 'sacrifices' they make while cooperating in production are heterogeneous quantities, which one would not know how to sum together" (ibid.). Towards the end of his Cours, Pareto wondered whether the "theory of comparisons of ophelimities" (that is, index-numbers of real income) would eventually lead to the concept of a "social aggregate" analogous to an "aggregate of material molecules" of the 
theory of elasticity in physics (ibid., t.II, p.409). That was before he developed the notion of individual and social indifference curves in the Manuel.

Pareto was not at the beginning sceptical of the analytical use of the aggregative concept of "society" in economics (2007 [1892-1893], p.64-74). In his cardinalist years he argued that the notion of "average marginal utility" of an aggregate of individuals was necessary for the investigation of the laws of exchange, as demand theory would be "useless if only applicable to single individuals" (ibid., p.73; see also Baranzini and Bridel, 2005). He assumed that there was no exchange between members of such an aggregate (called "society"), but only between that aggregate and the remaining individuals. ${ }^{5}$ Pareto claimed that whereas in "primitive societies the socio-economic unit may be the individual", with a better division of labour "the unit becomes an aggregate of many people, all of them offering certain commodities and requiring others" (ibid., p.65). He defined the average marginal utility of a commodity for that society as "that final degree of utility that for one individual would have as consequence the demand for the supply observed for the society" (ibid., p.64). It is clearly implied here the notion of a representative agent. ${ }^{6}$

The notion of representative households appeared also in the empirical sources used by economists and social scientists at the time. Economics was concerned with annual aggregate consumption data provided by general statistics, but that was also revealed by and compatible with the "much more detailed statistics compiled in accordance with Le Play's method" (Pareto, 2005 [1896I897], §928, p.8). He was referring to Frederic Le Play’s (1877-I879 [1855]) studies of consumption through the device of detailed investigations of the budgets of representative families in order to describe their standard of living. Le Play is generally regarded as the creator of the case-study method in social sciences. As described by Porter, “Le Play's budgets provided the basis for a

5 This is reminiscent of Jevons's "trading bodies". The same applies to the next quotation.

6 Lecouteux (2013) has argued that-since Pareto analyzed in his pure economics social market equilibrium and not isolated individuals-he defined the economic man as a representative agent, in the sense of the idealization of a group of individuals instead of the psychological behaviour of a real individual. The notion of representative agent, on the other hand, does not extend to Pareto's sociology, where heterogeneity prevails (Tusset, 20I3). 
microsociology in which the whole is made visible by the close analysis of a part", through the selection of a "typical or representative family" (201 I, p.297; see also Higgs 1890 for a contemporary assessment of Le Play's method). In his chapter about income distribution and consumption, Pareto referred extensively to family monograph studies made by the "Le Play School" (1964 [1896I897], §985-989). Changes in aggregate consumption would provide the foundation of Pareto's interpretation of business cycles.

\section{CONSUMPTION AND THE BUSINESS CYCLE}

Pareto's focus on average economic conditions was partly based on his view that the economic aggregate is in a "perpetual state of motion", as put in the title of the opening section of the Cours' chapter on "economic crises" (Pareto's term for business cycles). This was illustrated by the fluctuation of market prices around their long-run equilibrium values. Pareto (1964 [I896-I897], §ı I, §892) referred to Walras's tâtonnement (called marchandage by Pareto) as the mechanism through which the market solves the equations of general equilibrium. In reality, as pointed out by Pareto, equilibrium is never reached, for "as one tries to come closer [to equilibrium] it changes continuously because the technical and economic conditions of production change. The real state is therefore one of continuous oscillations around a central point of equilibrium, which is itself displaced” (ibid., §IoI). He used the mathematical notion of courbes de poursuite (also known as the "dog-and-his-master problem") to argue that the objective itself may change as a consequence of the means used to attain it, and the firm may travel along one of these "pursuit curves" (ibid., §4I; 197I [1909], chapter V, §II). Marchandage is carried out in real-life markets by means of "speculation", defined by Pareto as the operation through which entrepreneurs and traders try to approach, "as promptly as possible", the solution to the equations of economic equilibrium (1964 [I896-I897], §892, §90I). The perfect adaptation of production to consumption depends on the forecasts made by speculators, which are often inaccurate (Pareto, 197I [1909], chapter IX, §76-77). Pareto illustrated that in paragraph 4I of the Cours, with the help of pursuit curves: an increase in consumption causes a more than proportional increase of production, as entre- 
preneurs tend to believe that the increase in demand will continue indefinitely, that is, they provide not only for current demand but also for expected future demand. "This is one of the causes of production crises", he suggested.

Pareto's approach to the business cycle, however, was not built on the notion of oscillations around equilibrium. His suggestion of non-tâtonnement disequilibrium was just that, an underdeveloped suggestion. As pointed out by Schumpeter (1949, p.159), Pareto used it to show that the convergence to unique and stable equilibrium was more doubtful than Walras and others tended to believe, with no indication of how to elaborate a positive theory of dynamic disequilibrium though. It is worth noting that Pareto distinguished the business cycle from the continuous "vibrations of the molecules" of the economy in different directions. Those movements, which are related to the allocation of productive factors to different sectors of the economic aggregate, tend to offset each other. The business cycle, on the other hand, is about general states of economic depression or prosperity, when "almost all of these movements of the elements of the economic complexus occur in the same direction" (Pareto, I97I [1909], chapter IX, §73). That was the third and final stage in the study of pure economics:

The depiction of the economic phenomenon is now complete. We began by assuming that the molecules of the economic aggregate are in equilibrium; we then examined certain of their movements; lastly, we ventured the conception of an aggregate which is wholly in motion. By proceeding from the simple notion of ophelimity, we have thus succeeded in depicting extremely varied and complex phenomena (Pareto, 2005 [1896-1897], §927, p.6-7).

Pareto's contrast between partial over-production (compensated by partial under-production) on one side, and general changes in production on the other did not lead to the development of the concept of aggregate general over-production, which he rejected. Echoing orthodox views on Say's Law, he argued that "an excess of all productions is as absurd as an increase of all values. Some productions may well be in excess relative to some others, but this excess itself acts to bring the system to its equilibrium position" (I964 [I896-I897], t.II, p.406-407; see also I97I [1909], chapter IX, §83). Here again, he shared 
Jevons's company (1965 [1871], p.202-203). In paragraph 928 of his Cours, Pareto outlined an "essay on the dynamics of the economic aggregate" based on the study of the "conditions of equilibrium" of the economic system through time. Average consumption of commodities per unit of time, according to Pareto, was akin to velocities in physics. Pareto's notion of "dynamics" was heavily influenced by D’Alembert Principle and the corresponding notion of "inertia” in mechanics (Donzelli, 1997; Boianovsky and Tarascio, 1998). Because of their habits, economic agents change their demand and supply patterns only gradually. A change in the velocity of the consumption of commodity $A$ is expressed by $\mathrm{dr}_{\mathrm{a}} / \mathrm{dt}$ where $\mathrm{r}_{\mathrm{a}}$ means consumption of $A$ during a small unit of time (a "day"). The effort required by the individual to effect this change is the inertial function $f_{a}\left(\frac{d r_{a}}{d t}\right)$.

The equilibrium of the consumer is given by:

$$
\left(\varphi_{a}+f_{a}\right) \delta r_{a}+\left(\varphi_{b}+f_{b}\right) \delta r_{b}+\cdots=0
$$

where $\varphi_{\mathrm{a}}$ is the marginal ophelimity of commodity $A$. Moreover, the budget constraint of the consumer is given by:

$$
r_{a} p_{a}+r_{b} p_{b}+\cdots+r_{e}=r_{s} p_{s}+r_{t} p_{t}+\cdots
$$

where $S, T$... stand for the amounts of different kinds of capital (including human capital and land) owned by the individual, and $r_{e}$ is the amount of money he adds or withdraws from his savings. For entrepreneurs, the inertial function $\mathcal{F}_{a}\left(\frac{d R_{a}}{d t}, \ldots\right)$ measure the difficulties experiencing by them in changing their supply of commodity $A$. The equilibrium equations for entrepreneurs are therefore given by:

$$
p_{a}-\pi_{a}-\mathcal{F}_{a}=0, \quad p_{b}-\pi_{b}-\mathcal{F}_{b}=0, \ldots
$$

where $\pi_{a}$ is the cost of production of $A$. Equations (1), (2) and (3), together with equations (3), (5), (6) and (7) of paragraph 100 of the $\mathrm{Cours}^{7}$, gave what Pareto called "general equations for the dynamics of economic systems" (2005 [18961897], §928, p.10). The general equilibrium system of paragraph 100 is formed by

7 Which express costs of production of each commodity, amounts of commodities produced and factor services employed, and equality between the demand for factor services and the amounts employed. 
$\theta$ individuals, $\mathrm{m}$ commodities and $\mathrm{n}$ factor services, with $(\mathrm{m}+\mathrm{n}) \theta+\mathrm{m}+\mathrm{n}$ equations. One of the equations follows from the others because of the budget constraint, so that the number of independent equations is the same as the number of variables. This is a depiction of a non-monetary economy in full-employment equilibrium.

Pareto's main purpose in the chapter about economic crises was to demonstrate that the economic aggregate oscillates cyclically. In order to do that, he discussed a simplified version of the system described above, with a single individual. The individual is a rentier who receives a constant flow of income $r_{s}$, spends part of it on the only good $A$ and saves the rest $r_{\mathrm{e}}$. The only economic decision made by the rentier is the date of consumption of $A$. As explained by Pareto in section 108 of the book, two goods materially identical are "economically distinct if they are not in the same place or cannot be enjoyed at the same time". Hence, his was a model with two physically identical commodities consumed at different dates by a single agent. Pareto further assumed that "prices are constant" (2005 [1986-I897], §928, p.I0). In the context of his model, this meant that the rate of interest (relative price of $A$ at different dates) is constant. The first order condition is:

$$
\frac{1}{p_{a}}\left(\varphi_{a}-f_{a}\right)=\varphi_{e}-f_{e}
$$

and the budget constraint is:

$$
r_{a} p_{a}+r_{e}=r_{s}
$$

Pareto put $r_{a}=\alpha+x$ where $\alpha$ is a constant and $x$ a small variable quantity. By making some assumptions and using Taylor expansion, he obtained a differential equation in $x$, whose cyclical solution was given by $x=(I / h) \sin (c+k h t)$, where $k$ is an integral constant and $c$ an arbitrary constant. The model, claimed Pareto, shows that " $x$ is a periodic function, and consumption perpetually fluctuates around the value $\alpha$, in diverging from it by at most (I/h)" (ibid., p.I I). Pareto's result that consumption follows a cyclical path of constant amplitude led him to claim that the "general equations we have just obtained for the economic aggregate" are a "remarkable" depiction of "all the observable phenomena" and 
represent the "best proof" that the general equilibrium system is in "complete harmony with the nature of things" (ibid.).

As it happens, Pareto's model was mathematically flawed, as first shown by Knut Wicksell (1958 [1899]) in his German review of volume 2 of the Cours. ${ }^{8}$ Given the assumptions of the model, consumption is not cyclical but converges to a single value (for details see Benhabib, I979; Boianovsky and Tarascio, 1998). However, our main interest here is not to discuss the mathematical structure of Pareto's model, but its economic features. Jess Benhabib (1979) has rectified Pareto's inertial model by assuming that utility depends positively on the levels of consumption and leisure and positively (negatively) on increases (decreases) in consumption and leisure. He concluded that consumption and leisure oscillate cyclically in a Paretian model with habit formation. Benhabib's is a representative agent model with consumption and leisure, instead of consumption and saving. Pareto's model of cyclical consumption may in principle be interpreted as a representative agent model as well. He maintained that his theoretical results established cyclical changes in aggregate consumption as the main fact to be investigated in the study of economic fluctuations.

The symptoms of crises are now clear. If we knew the velocities at which goods are produced and consumed, our knowledge of the movements that constitute the crisis would, according to earlier statements (\$928), be perfect. But statistics are incapable of providing us with such comprehensive information. It is therefore a matter of searching among the easily observable facts (Pareto, 2005 [1896-1897], §939, p.16).

In the absence of annual information about consumption, Pareto found a proxy in data about changes in the velocity of circulation of money and in bank reserves and deposits collected by Pierre des Essars, Clément Juglar and others. Again, he referred to his model of paragraph 928 when stating that "it is quite

8 There is no evidence that Wicksell and Pareto corresponded about the Cours. Pareto acknowledged in a letter of 5 March 1894 (in the Wicksell Papers, Lund University Library) receipt of Wicksell's Wert, Kapital und Rente, but informed that he could not understand it properly due to his imperfect knowledge of German. Anyway, Pareto eventually admitted that the model of paragraph 928 was mistaken (see Boianovsky and Tarascio, 1998). 
remarkable that the rational study of crises leads us directly to seek the origin of crises in variations in the velocities of receipts and debts (§928)" (ibid., §945, p.20).

Even if the model of an individual agent provided the foundations of Pareto's interpretation of the business cycle, he felt compelled to discuss why individuals in general would move in the same direction and bring about aggregate fluctuations in consumption and, therefore, in production. Business cycles occur when the "vibrations" that affect the economic aggregate become "synchronic" instead of counteracting each other (ibid., §929, p.I2; I97I [1909], chapter IX, §78). The similarities between individuals in the economic realm mean that they share a common behaviour and reaction pattern, just like in physics the vibrations of molecules "interfere with and overlay with each other" (Pareto, 2005 [1896-1897], §926, p.6). The movement of a "single molecule" of the economic aggregate will gradually attract the others, reflecting the existence of forces ensuring that the "molecules of the economic aggregate are closed link” (ibid., §929, p.I2). Hence, it was homogeneity instead of heterogeneity among agents that mattered for Pareto's economic approach to business cycles. He found in the notion of "resonance" yet another physical metaphor to illustrate his argument:

We then observe a similar phenomenon to that known in physics as 'resonance'. If we take several crystal glasses of various dimensions and cause one to vibrate, the others remain still. But if all the glasses are the same size and capable of sounding the same note, the others will pick up the vibration and the sound is considerably augmented (ibid.).

The model of an individual consumer developed in paragraph 928 is valid on the grounds that consumers as a whole tend to act the same way. Wicksell thought that Pareto's model of a single rentier would be able to generate a wavelike movement in the aggregate only if "perchance the behaviour of many individuals is influenced in the same direction", with no reference to the "resonance" argument (1953 [1907], p.59). Pareto distinguished "subjective" from "objective" synchronism. The first was defined as the "capacity of the greatest number of people in a given society to experience at a certain moment feelings that make them behave in the same way" (2005 [1896-1897], §930, p.I2). Objective 
synchronism resulted from changes in the parameters of economic equilibrium affecting a large number of individuals, such as technical progress, food shortages, or changes in tastes. Probably because he did not envisage a hypothesis about cyclical changes in the conditions of economic equilibrium, Pareto stressed subjective instead of objective synchronism. He applied the notion not only to his model of cyclical consumption, but also to aggregative shifts in l'état d'esprit des hommes (1964 [1896-1897], §934) capable of producing alternate periods of overconfidence and general mistrust (see also Pareto, I97i [1909], chapter IX, §79). It is possible to find in Pareto's chapter on crises the notion of waves of pessimism and optimism determined by overshooting in individuals' adaptation to their expectations (Kirman, I998, p.19). However, Wicksell's critical interpretation-that Pareto assumed that "the individual or society could forecast the future with certainty” (1953 [1907], p.60) - fits better not just the model of paragraph 928 but the central message of the chapter as a whole. Indeed, Pareto eschewed anti-cyclical policies (1964 [1896-1897], §949); see also Bridel, 2012). His statement that business cycles "are not caused by the 'abuse of credit': they would occur if credit did not exist” (2005 [1896-1897], §93 I, p.I3) is fully consistent with his formal equilibrium model. ${ }^{9}$

Pareto (2008 [190I]) would make yet another attempt to put forward equations of motion of the economic aggregate, this time without using the notion of "inertia" or "habit". Instead of dealing with periods or intervals of time and changes in velocities, he assumed an economy progressing in continuous time. Growth economics is the natural territory of macroeconomics, since the economic system as a whole moves in the same direction. The number of individuals, commodities and productive factors is the same as in the general equilibrium system of paragraph soo of the Cours. There is capital accumulation, but no population growth. In that sense, it is a multi-commodity model, not a fully-fledged aggregative growth model as Gustav Cassel would advance for the first time later. Pareto, however, attempted to move towards an aggregative level. In order to simplify notation, he wrote the 
consumption and saving equations for a single individual only, which were (implicitly) "repeated for all individuals". But he now used the symbol $\sum$ to represent a "sum extended to all the individuals in the community" (Pareto, 2008 [I90I], p.505-506). Aggregate income and aggregate expenditure were treated as the sum of individual values, with no distinction among individual functions or an explanation of the aggregation procedure. From a broad perspective, Pareto's I90 I equations of dynamic equilibrium were based, like the previous ones in his Cours, on the generalization of the saving behaviour of a single individual. In both cases Pareto stopped short of developing an aggregative model of savings and growth.

\section{CONCLUSION}

Pareto's model of the rentier in paragraph 928 of his Cours should be understood as an exercise in the dynamics of the "individual economy". It provided the backbone of his approach to business cycles as regular oscillations in aggregate consumption. Although Pareto recanted the model in his Manuel, he kept discussing economic fluctuations of the economic aggregate in terms of changes in production led by the cyclical pattern of consumption. This accorded with his overall general equilibrium perspective, which saw consumer behaviour as the leading factor in the working of the economic system. Like Irving Fisher (196I [I892], chapters 4-6) - and similarly to the later ArrowDebreu approach to general equilibrium as well-Pareto did not aggregate individual functions in his general equilibrium system. However, unlike Fisher and several other contemporary neoclassical economists, he did not deploy the quantity theory of money as a benchmark to study nominal and real aggregate dynamics. ${ }^{10}$ Again unlike his contemporaries, Pareto attempted a treatment of aggregate economic fluctuations as determined by the optimizing behaviour of economic agents in equilibrium, although without much success.

10 Pareto's critical attitude toward the quantity theory of money was developed in chapter II of Book I of his Cours. 
Attractive as it was, general equilibrium analysis was beset by the so-called Cournot problem. Pareto's approach to business cycles was consistent with his general concern with average variables in economics. Like Jevons before him, Pareto focused not on the diversity of behaviour across individuals, but on average or aggregate patterns. However, it was not always clear how exactly such average entities should be constructed. Whereas Jevons put forward the notion of "trading bodies" to cope with differences among individuals, Pareto did not explain how to combine general equilibrium modelling with average phenomena. Jevons suggested, for example, that countries are regarded as trading bodies and the utility function (or indifference map, in Paretian terminology) of a country is used in international trade theory. It was only much later that it became clear that such social indifference curves could only be built on the assumption of identically homothetic utility functions for all individuals (Gorman, 1953; Chipman, 1965). Pareto's argument often came close to the notion of a representative agent, both in his microeconomics and in his treatment of the motion of the economic aggregate. Differently from his sociology-dominated as it was by social heterogeneity revealed by Pareto's Law of income distribution-Pareto's pure economics assumed relative homogeneity across individuals. Sometimes, as in his 1907 letter to Furlan quoted above, he went as far as assuming that all individuals are identical. On other occasions, he borrowed the concept of resonance from physics to illustrate the consequences of general similarities among economic agents.

Surely, the representative agent in modern macroeconomics is not an average or typical individual (see Kirman, 1992). It has been sometimes illustrated by the Crusoe economy, a concept rejected by Pareto. Moreover, it applies strictly to models in which the behaviour of a single infinitely lived optimizing agent represents the macroeconomic behaviour of the aggregate of economic agents. The acknowledged influence is Ramsey (1928), but the concept of a representative infinitely lived individual made its first appearance in Wicksell's discussion of saving (see Boianovsky, 20ı3, a companion to this article). Wicksell neither extended that notion to his well-known discussion of the cumulative process, nor did he recognize the notion of 
a representative agent in Pareto's business cycle model. The view that the logic of aggregate changes-as indicated by the new concepts of aggregate demand and supply introduced by Wicksell and further elaborated as one of the foundations of macroeconomics in the I93os-differs from strictly microeconomic reasoning was still foreign to Pareto. Instead, he sought in his microeconomic general equilibrium the analytical tools capable of illuminating the dynamics of the economic aggregate.

AN. I would like to thank Guido Erreygers for bibliographical support. A grant from CNPq (Brazilian Research Council) is gratefully acknowledged.

\section{BIBLIOGRAPHY}

BACKHOUSE R.E., M. BOIANOVSKY, 2013, Transforming Modern Macroeconomics: Exploring Disequilibrium Microfoundations, 1956-2003, Cambridge, Cambridge University Press.

BARANZINI R., BRIDEL P., 2005, “L'École de Lausanne', l'utilité marginale moyenne et l'idée de marché", in Histoirie des representations du marché, ed. by G. Bensimon, Paris, Houdiard, p.347-365.

BENHABIB J, 1979, "Pareto vs Wicksell on Adjustment Costs in Consumption-a Reformulation", Economics Letters, 2, p. 121 - 124.

BÖHM-BAWERK E., I89I ( 889 ), The Positive Theory of Capital, New York, Stechert.

-, I891, "The Austrian Economists", Annals of the American Academy of Political and Social Science, I, p.36l-384.

BOIANOVSKY M., 200I, "Economists as Demographers: Wicksell and Pareto on Population", in Economics and Interdisciplinary Exchange, ed. by G. Erreygers, London, Routledge, p.117-149.

-, 2013, Wicksell and the idea of macroeconomics, Unpublished typescript.

-, TARASCIO V., 1998, "Mechanical Inertia and Economic Dynamics: Pareto on Business Cycles", Journal of the History of Economic Thought, 20, p.4-23. 
-, TRAUTWEIN H.-M., 2003, "Wicksell, Cassel and the Idea of Involuntary Unemployment", History of Political Economy, 35, p.385-436.

BRIDEL P., 2012, "Walras and Pareto on the Connection Between the Trade Cycle and General Equilibrium Theory", in Macroeconomics and the History of Economic Thought, ed. by H. Krämer, H. Kurz and H.-M. Trautwein, London, Routledge, p.78-95.

BRUNI L., 2009, "Pareto's Methodological Project", in New Essays on Pareto's Economic Theory, ed. by L. Bruni and A. Montesano, London, Routledge, p.5-29.

CHIPMAN J.S., 1965, "A Survey of the Theory of International Trade, Part 2", Econometrica, 33, p.685-760.

COURNOT A., I897 (1838), Researches into the Mathematical Principles of the Theory of Wealth, New York, Macmillan.

DAAL (van) J., WALKER D., 1990, "The Problem of Aggregation in Walras's General Equilibrium Theory", History of Political Economy, 22, p.489-505.

DEMARIA G., 1952 (1949), "Demaria on Pareto", in The Development of Economic Thought, ed. by H.W. Spiegel, New York, Wiley, p.629-65I.

DE VROEY M., 2004, "The History of Macroeconomics Viewed against the Background of the Marshall-Walras Divide", in The IS-LM model: its Rise, Fall, and Strange Persistence, ed. by M. De Vroey and K.D. Hoover, Annual Supplement to History of Political Economy, Durham, Duke University Press, p.57-91.

DONZELLI F., 1997, “Pareto's Mechanical Dream”, History of Economic Ideas, 5, p. 127- 178.

FISHER I., 1961 (1892), Mathematical Investigations in the Theory of Value and Prices, New York, Kelley.

FRIEDMAN M., 1955, "Leon Walras and His Economic System: a Review Article", American Economic Review, 45, p.900-909.

GORMAN W.M., 1953, "Community Preference Fields", Econometrica, 21, p.63-80. HARTLEY J.E., 1997, The Representative Agent in Macroeconomics, London, Routledge. HAYEK F., 1942, "Scientism and the Study of Society, part l", Economica, 35, p.267-29l. -, 1975, "The Pretence of Knowledge", The Scandinavian Journal of Economics, 77, p.433-442. 
HICKS J., 1937, "Mr Keynes and the Classics: a Suggested Interpretation", Econometrica, 5, p.147-I59.

-, 1946 (1939), Value and Capital, $2^{\text {nd }}$ edition, Oxford, Clarendon Press.

HIGGS H., 1890, "Frédéric Le Play", Quarterly Journal of Economics, 4, p.408-433.

HOOVER K.D., 1988, The New Classical Macroeconomics, Oxford, Blackwell.

INGRAO B., ISRAEL G., 1990, The Invisible Hand: Economic Equilibrium in the History of Science, Cambridge (Mass.), MIT Press.

JEVONS W.S., 1965 (I87I), The Theory of Political Economy, New York, Kelley.

KIRMAN A.P., 1992, "Whom or What Does the Representative Individual Represent?", Journal of Economic Perspectives, 6, p. I17-136.

KIRMAN A.P., 1998, "Vilfredo Pareto" in Italian Economists of the 20 ${ }^{\text {th }}$ Century, ed. by F. Meacci, Cheltenham, Elgar, p.II-43.

LE PLAY F., 1877-I879 (I855), Les Ouvriers européens, 2 ${ }^{\text {nd }}$ edition, Tours, Alfred Mame et fils.

LECOUTEUX G., 2013, "Reconciling Behavioural and Neoclassical Economics", École Polytechnique, Départment d'Économie, Cahiers, 2013-09.

MANESCHI A., 1993, "Pareto on International Trade Theory and Policy", Journal of the History of Economic Thought, 15, p.210-228.

MARCHIONATTI R., GAMBINO E., 1997, "Pareto and Political Economy as a Science: Methodological Revolution and Analytical Advances in Economic Theory in the 1890s", Journal of Political Economy, 105, p. 1322-1348.

MARSHALL A., 1990 (1890), Principles of Economics, London, Macmillan.

MORNATI F., 2008, "Vilfredo Pareto's Correspondence as a Significant Source for the Knowledge of His Economic Thought", in The Anti-Keynesian Tradition, ed. by R. Leeson, London, Palgrave, p. 173-204.

MOSSELMANS B., 2005, "Adolphe Quetelet, the Average Man and the Development of Economic Methodology", European Journal of the History of Economic Thought, 12, p.565-582.

NEGISHI T., 1989, History of Economic Theory, Amsterdam, North-Holland. 
PARETO V., 1897, "The New Theory of Economics", Journal of Political Economy, 5, p.485-502.

-, 1935 (1916), The Mind and Society, 4 vols, New York, Harcourt, Brace and Co.

-, 1955 (19II), "Mathematical Economics", International Economic Papers, 5, p.58-I02.

-, 1963 (1898), "Comment se pose le problème de l'économie pure", Cahiers Vilfredo Pareto / Revue européenne d'histoire des sciences sociales, I, p. I21-130.

-, 1964 (1896-1897), Cours d'Économie politique, Fuvres complètes, t.I-II, Genève, Droz.

-, 197I (1909), Manual of Political Economy, London, Macmillan.

-, 1975, Correspondance: 1890-1923, Furres complètes, t.XIX, Genève, Droz.

-, 2005 (1896-1897), "Economic Crises", in Business Cycle Theory-Selected Texts 1860-1939, vol.VIII ("Quantitative Business Cycle Analysis"), ed. by M. Boianovsky, London, Pickering \& Chatto, p.3-22.

-, 2007 (1892-1893), Considerations on the Fundamental Principles of Political Economy, ed. by R. Marchionatti and F. Mornati, London, Routledge.

-, 2008 (1900), "Summary of Some Chapters of a New Treatise on Pure Economics by Professor Pareto", Giornale degli Economisti e Annali di Economia, 67, p.453-504.

-, 2008 (1901), "The Equations of Dynamic Equilibrium", Giornale degli Economisti e Annali di Economia, 67, p.505-513.

POMINI M., TUSSET G., 2009, "Habits and Expectations: Dynamic General Equilibrium and the Italian Paretian School", History of Political Economy, 4I, p.311-342.

PORTER T., 20II, "Reforming Vision: the Engineer Le Play Learns to Observe Society", in History of Scientific Observations, ed. by L. Daston and E. Lynbeck, Chicago, University of Chicago Press, p.28I-302.

QUETELET A., 199| (I835), Sur l'homme, Paris, Fayard.

SARGENT T., 1979, Macroeconomic Theory, New York, Academic Press.

SCHUMPETER J.A., 1949, "Vilfredo Pareto (1848-1923)", Quarterly Journal of Economics, 63, p.147-173.

-, 1954, History of Economic Analysis, New York, Oxford University Press. 
SOLOW R., 2007, "Cournot and the Social Income", in Augustin Cournot: Modelling Economics, ed. by J.-P. Touffut, Cheltenham, Elgar, p.106-II5.

TARASCIO V., 1969, "The Monetary and Employment Theories of Vilfredo Pareto", History of Political Economy, I, p.101-122.

TEIRA D., 2006, "A Positivist Tradition in Early Demand Theory", Journal of Economic Methodology, 13, p.25-47.

TUSSET G., 2013, "How Heterogeneity Shapes Vilfredo Pareto's Social Equilibrium" History of Economics Review, 57, p.47-62.

WALRAS L., 1954 (1874), Elements of Pure Economics, London, Allen \& Unwin.

WEINTRAUB E.R., 1979, Microfoundations-The Compatibility of Microeconomics and Macroeconomics, Cambridge, Cambridge University Press.

WHITE M., 1987, "Robinson Crusoe", in The New Palgrave Dictionary of Economics, vol.4, ed. by J. Eatwell, M. Milgate and P. Newman, London, Macmillan, p.217-218.

-, 1994, "Bridging the Natural and the Social: Science and Character in Jevons's Political Economy", Economic Inquiry, 32, p.429-444.

-, 200I, "Indeterminacy in Exchange: Disinterring Jevons' 'trading bodies"', Manchester School, 69, p.208-226.

WICKSELL K. 1958 (1899), "Vilfredo Pareto's Cours d'Économie politique”, 2, in Selected Papers on Economic Theory, ed. by E. Lindahl, London, Allen \& Unwin, p. $151-158$.

-, 1953 (1907), "The Enigma of Business Cycles", International Economic Papers, 3, p.58-74. 
